EISSN: 2706-7955 ISSN: 2077-4605

DOI: 10.36632/mejar/2021.10.3.68

Journal homepage: www.curresweb.com

Pages: 1031-1039

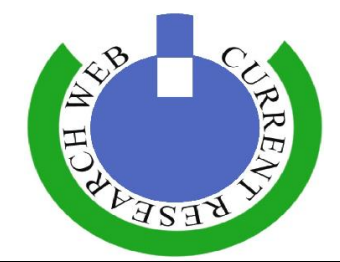

\title{
Potassium Sources and Its Effect on the Yield and Quality of Maize Crop under Fertigation in Sandy Soil
}

\author{
Reda E. Essa ${ }^{1}$, Soad M. El-Ashry ${ }^{2}$, Foukia E. Mouafi ${ }^{3}$ and Manal F. Mohammed ${ }^{1}$ \\ ${ }^{1}$ Field Crop Research Department, National Research Centre, 33 El Buhouth St., 12622 Dokki, Giza, \\ Egypt. \\ ${ }^{2}$ Soils and Water Use Department, National Research Centre, 33 El Buhouth St., 12622 Dokki, Giza, \\ Egypt. \\ ${ }^{3}$ Microbial Biotechnology Department, National Research Centre, 33 El Buhouth St., 12622 Dokki, \\ Giza, Egypt.
}

Received: 20 July 2021

Accepted: 15 Sept. 2021

Published: 30 Sept. 2021

\begin{abstract}
Improving the production and quality of maize crops is the fundamental objective of farmers. A during the two seasons 2018 and 2019 field tests were directed to study the impact of potassium fertilizers on the development and productivity of fertigated maize variety (Giza 10) in sandy soil in Wadi ElNatroun, El-Behaira governorate, Egypt. The design of the trial was a split split-plot design in a randomized full-block concurrence with three replications. The results showed that the addition of potassium sources significantly increased the growth parameters, yield, and chemical constituents of the maize variety under fertigation in sandy soil conditions. There was a critical yield contrast between potassium sulphate and potassium chloride treatments. By and large, the maximum mean values of all parameters in the prose of study were acquired from the maize variety when the plants were fertilized by $75 \mathrm{~kg} /$ fed potassium sulphate. It could be concluded that at long last, to improve the yield and quality of maize under irrigation water sandy soil adding potassium sulphate $75 \mathrm{~kg} / \mathrm{fed}$ with 2-weeks pattern and it has been powerful to realize some new innovations to improve the productivity of maize in sandy soil.
\end{abstract}

Keywords: Potassium chloride, Potassium sulfate, irrigation water.

\section{Introduction}

Maize (Zea mays L.) is one of the most deliberately grown cereal crops in Egypt. It has great incredible significance as a wellspring of human food, animal feed and crude material of countless number of industrial products. Maize is widely grown in numerous nations on the planet. Its fundamental capacities are to serve constituents of numerous significant natural compounds and take an interest in many essential metabolic processes in plants. (Davis 2019).

Potassium $(\mathrm{K})$ is a fundamental supplement for the ideal production of corn crops. It is associated with the initiation of compounds inside the plant, which influences the production of protein, starch, and adenosine triphosphate. Potassium additionally assists with managing the opening and shutting of stomata, which control the trading of water vapor, oxygen, and carbon dioxide (Barker and Pilbeam 2015).

It works on the general soundness of growing plants and assists them with fight infections. Potassium influences quality factors like the size, shape, color, and power of seeds or grains. Fertigation can build manure proficiency, which lessens compost prerequisites and amplifies water use efficiency to accomplish the best outcomes (Mulyati et al., 2021).

The role of $\mathrm{K}$ in the growth of potato plants, in the biochemistry of starch synthesis, in the quantity and quality of tubers is well documented in the literature all around archived in the literature (Karam et al., 2011). While, Muhammad et al., (2011) indicated that the impact of $\mathrm{K}$ as far as sulfate 
and chloride of potassium on the growth performance of maize crop was found factual contrasts, since chloride of potassium leaches down the profile with irrigation water and doesn't amass in the root zone.

Potassium application rates as fertilizer sources ought to be founded on the natural necessities of the plant. Therefore, Khan et al., 2012 review audit expects to give ideal data on the advancement of diet $\mathrm{K}$ for potato cultivation regarding source, application technique, application rate, and timing.

Potassium has significant capacities in plant water relations where it regulates ionic equilibriums inside cells, furthermore it assumes an important role in the activation of in excess of 60 enzymes that catalyze different metabolic processes. As, the take-up and movement of nitrates from roots to aerial pieces of plants (Tränkner et al., 2018).

Thusly, the target of this study was to assess the impact of various rates and pattern of potassium sulfate and potassium chloride on the quality and total yield of maize under fertigation in sandy soil conditions.

\section{Materials and Methods}

\subsection{Experimental Site}

In this study, field experiments were conducted over two successive seasons of 2018 and 2019 in Wadi El-Natroun, El-Behaira Governorate, Egypt. This study aims to investigate the effect of potassium sources, rates and pattern on yield components and quality of fertigated corn (Giza 10) under sandy soil conditions.

A representative soil sample (0 to 30) was taken from the experimental field prior to sowing for each season to determine physical and chemical characteristics. The chemical properties of the soil were determined by standard procedures using soil extract solutions. The electrical conductivity (EC) was measured using a conductivity meter (Nelson and Sommers, 1982) and the chemical analysis of the soil and irrigation water used is presented in tables (1 and 2) according to the method described by Cottenie et al., (1982).

Table 1: Physical and chemical properties of the experimental site before sowing.

\begin{tabular}{|c|c|c|c|c|c|}
\hline \multicolumn{2}{|c|}{ Particle size distribution (\%) } & \multicolumn{2}{|l|}{ Chemical analysis } & \multicolumn{2}{|c|}{ NPK $(\mathrm{mg} / \mathrm{kg})$} \\
\hline Clay & 4.60 & pH (1:2.5) & 7.90 & $\mathbf{N}$ & 33.00 \\
\hline Silt & 5.10 & $E C d^{2} m^{-1}(1: 5)$ & 0.36 & $\mathbf{P}$ & 4.90 \\
\hline Fine sand & 22.70 & $\mathrm{CaCO}_{3}(\%)$ & 3.58 & $\mathbf{K}$ & 65.00 \\
\hline Coarse sand & 67.60 & O.M (\%) & 0.08 & & \\
\hline Texture class & Sandy & & & & \\
\hline
\end{tabular}

Table 2: Chemical analysis of irrigation water.

\begin{tabular}{|c|c|c|c|c|c|c|c|c|c|}
\hline \multirow[t]{2}{*}{ pH } & \multirow{2}{*}{$\begin{array}{c}E C \\
\text { dSm }^{-1}\end{array}$} & \multicolumn{4}{|c|}{ Soluble cations $(\mathrm{mg} / \mathrm{L})$} & \multicolumn{4}{|c|}{ Soluble anions (mg/L) } \\
\hline & & $\mathbf{K}^{+}$ & $\mathbf{N a}^{+}$ & $\mathbf{M g}^{2+}$ & $\mathbf{C a}^{2+}$ & $\mathrm{CO}_{3}{ }^{2-}$ & $\mathrm{HCO}_{3}^{-}$ & $\mathrm{Cl}^{-}$ & $\mathrm{SO}_{4}{ }^{2-}$ \\
\hline 7.82 & 0.90 & 3.21 & 3.12 & 6.42 & 7.25 & 0.00 & 3.91 & 0.60 & 15.46 \\
\hline
\end{tabular}

\subsection{Experimental design}

Field experiments in both seasons were conducted under a drip irrigation system with a distance of $30 \mathrm{~cm}$ between drippers $(2 \mathrm{~L} /$ hour $)$ and $60 \mathrm{~cm}$ between rows. The plot size was $15 \mathrm{~m}^{2}(1 / 280 \mathrm{fed})$. Each plot consisted of five ridges $5 \mathrm{~m}$ long and $0.7 \mathrm{~m}$ wide. Irrigation was at intervals of 3-5 days. A split-split plot plan in a randomized complete block arrangement was used with three replicas.

The main plots were allocated to the two sources of potassium sulphate, $\left(\mathrm{K}_{2} \mathrm{SO}_{4}\right) 48-50 \% \mathrm{~K}_{2} \mathrm{O}$ and potassium chloride, $(\mathrm{KCl}) 60-62 \% \mathrm{~K}_{2} \mathrm{O}$ three levels of potassium $(25,50$ and $75 \mathrm{~kg} \mathrm{~K} 2 \mathrm{O} / \mathrm{fed})$ alongside treatment without potassium fertilization were allocated to the sub-plot and three application pattern (A week, two weeks and month) were allocated to the sub-sub plot. In the case of fertigation treatment, the $\mathrm{K}$ fertilizers were dissolved in sufficient water and their dissolved part was used for fertigation.

\subsection{Cultural practices}

Maize was sown on mid-May in the $1^{\text {st }}$ and $2^{\text {nd }}$ seasons. Maize (Giza 10) at a rate of $5 \mathrm{~kg} / \mathrm{fed}$ ( $\mathrm{fed}=4200 \mathrm{~m}^{2}$ ) was sown on both sides of the ridge in hills $30 \mathrm{~cm}$ apart and one plant/hill was left to 
thinning (Giza 10). The variety was obtained from the Maize Research Department, Field Crop Research Institute, Agricultural Research Center, Egypt .

The nitrogen fertilizer was added at a rate of $120 \mathrm{~kg} \mathrm{~N} /$ fed in the form of ammonium nitrate $(33.5 \% \mathrm{~N})$ in three equal doses starting after thinning and at intervals of 15 days. Phosphorus was added at the rate of $60 \mathrm{~kg} \mathrm{P}_{2} \mathrm{O}_{5} /$ fed as super calcium phosphate fertilizer $\left(15.5 \% \mathrm{P}_{2} \mathrm{O}_{5}\right)$ before sowing .

Potassium was added in the form of (potassium sulphate $\left(\mathrm{K}_{2} \mathrm{SO}_{4}\right) 48-50 \% \mathrm{~K}_{2} \mathrm{O}$ and (potassium chloride $(\mathrm{KCl}) 60-62 \% \mathrm{~K}_{2} \mathrm{O}$. Three potassium levels were used 25,50 and $75 \mathrm{~kg}$ of $\mathrm{K}_{2} \mathrm{O} / \mathrm{fed}$ alongside a treatment without potassium fertilization dose recommended by the Ministry of Agriculture. The pattern of potassium was as follows: once/week, once/2weeks and once/month. Potassium was added after 60 days of sowing.

Weed control was carried out during the growing season by hoeing four to 30, 40, 50 and 60 days after sowing. Also pest control, if necessary, was carried out according to the practices used at the experimental station. Other cultural practices were implemented in accordance with the recommendations of the Egyptian Ministry of Agriculture.

\subsection{Yield and its components}

Samples of ten kept plants were randomly collected from each plot at the three replications to measure growth parameters at 150 days after sowing, were, plant height $(\mathrm{cm})$, cereal and straw yield (ton/fed.). After harvesting of each plants plot grain and straw yields (ton/fed.) were determined by multiplying grain and straw yields/plot*280.

\subsection{Chemical analysis}

Wet digestion of plant sample $(0.5 \mathrm{~g})$ by acid mixture (perchloric-nitric, $\mathrm{v}$ : $\mathrm{v}$ ) was performed. The digest was quantitative transferred, diluted $(50 \mathrm{ml}$ distill water) and filtered on an ash-free filter paper. The filtrate was used for $\mathrm{K}, \mathrm{Na}, \mathrm{Ca}, \mathrm{Fe}, \mathrm{Zn}, \mathrm{Mn}$ and $\mathrm{Cu}$ directly by Atomic Absorption, while phosphorous was spectrophotometrically measured through the vanadate method (Carter and Gregorich, 2008).

Total nitrogen content in grains was determined by the Micro-Kjeldahl method, while crude protein \% was calculated as $\mathrm{N} \%$ x 6.25 according. Total Carbohydrates content were determined according to Dubois et al., (1956).

Oil (\%) was determined according to the American Oil Chemists Society-A.O.C.S (1990). The total carbohydrate content was determined according to Dubois et al., (1956).

Phosphorus was determined by Spectro-photometry using the method described by Cottenie, et al., (1982). The concentrations of $\mathrm{K}^{+}$were determined by an emission flame photometer. The concentration of $\mathrm{Ca}^{2+}$ and $\mathrm{Mg}^{2+}$ was measured by titration with a standard EDTA solution (Bao, 2000) .

\subsection{Statistical analysis}

The obtained data were statistically analyzed by analysis of variance (ANOVA), comparison of means using Costat Edition 6.3 software, and differences between means were determined by least significant differences (LSD) at a level of 5\% according to Snedecor and Cochran (1990).

\section{Results}

\subsection{Plant height}

Plant height is a significant part of straw yield and can likewise impact grain yield. The growth and improvement of a plant rely upon the cultivated species, the quantity of supplements in the local soil, furthermore the measure of the applied manure and ecological conditions during the growing season.

The data in Table (3) showed that the all potassium fertilizer sources significantly increased corn plant height over the two seasons. The increase in plant height in both seasons was recorded by potassium sulphate more than potassium chloride in both seasons. The greatest height of the plants was 277.00 and $305.52 \mathrm{~cm}$ with $75 \mathrm{~kg}$ of $\mathrm{K}_{2} \mathrm{O} /$ fed with 2 weeks with potassium sulphate.

Potassium sulphate far exceeded surpassed potassium chloride in plant height in both seasons, that is may be due to that potassium chloride is draining leaching than potassium sulphate during irrigation. Similarly, the increase in the K level increased maize plant height. Potassium sulphate is 
expanded worth as a $\mathrm{K}$ fertilizer since, it contains sulphur; it enhances the action of containing enzymes (Pettigrew 2008).

Table 3: Effect of different potassium sources of application on plant height of maize plants grown under fertigation system in both seasons.

\begin{tabular}{|c|c|c|c|c|c|c|c|c|c|}
\hline \multirow{3}{*}{ Fertilizers } & \multirow{3}{*}{$\begin{array}{c}\text { Rates } \\
\text { (Kg/fed.) }\end{array}$} & \multicolumn{3}{|c|}{ Pattern } & \multirow[b]{2}{*}{ Mean } & \multicolumn{3}{|c|}{ Pattern } & \multirow[b]{2}{*}{ Mean } \\
\hline & & $\begin{array}{c}\text { A } \\
\text { week }\end{array}$ & $\begin{array}{c}\text { Two } \\
\text { weeks }\end{array}$ & Month & & A week & $\begin{array}{c}\text { Two } \\
\text { weeks }\end{array}$ & Month & \\
\hline & & \multicolumn{4}{|c|}{2018} & \multicolumn{4}{|c|}{2019} \\
\hline Control & 0.0 & 235.17 & 237.17 & 235.34 & 235.89 & 257.79 & 260.74 & 258.16 & 258.90 \\
\hline \multirow{3}{*}{$\begin{array}{c}\text { Potassium } \\
\text { sulphate }\end{array}$} & 25 & 245.23 & 256.00 & 248.00 & 249.74 & 268.87 & 283.91 & 280.81 & 277.86 \\
\hline & 50 & 256.41 & 268.00 & 267.33 & 263.91 & 274.59 & 297.52 & 292.52 & 288.21 \\
\hline & 75 & 262.58 & 277.00 & 269.00 & 269.53 & 288.19 & 305.52 & 297.52 & 297.08 \\
\hline \multirow{3}{*}{$\begin{array}{c}\text { Potassium } \\
\text { chloride }\end{array}$} & 25 & 243.53 & 250.33 & 246.00 & 246.62 & 262.78 & 280.57 & 275.79 & 273.05 \\
\hline & 50 & 253.95 & 264.33 & 262.67 & 260.32 & 270.49 & 285.36 & 283.91 & 279.92 \\
\hline & 75 & 260.32 & 270.33 & 267.33 & 265.99 & 284.58 & 292.41 & 288.50 & 288.50 \\
\hline \multicolumn{2}{|c|}{ Mean } & 251.03 & 260.45 & 256.52 & 256.00 & 272.47 & 286.58 & 282.46 & 280.50 \\
\hline \multirow{3}{*}{ LSD $_{0.05}$} & & Sources & \multicolumn{2}{|c|}{7.40} & & \multicolumn{4}{|c|}{6.22} \\
\hline & & Rates & \multicolumn{2}{|c|}{7.30} & & \multicolumn{4}{|c|}{4.15} \\
\hline & & Pattern & \multicolumn{2}{|c|}{6.42} & & \multicolumn{4}{|c|}{4.32} \\
\hline
\end{tabular}

\subsection{Grain yield (ton/fed)}

Table (4) uncovered that all treatments significantly increased cereal yield over the two seasons. As, several studies indicated that potassium sulphate and potassium chloride fertilizers enhanced maize yield (Davis 2019). Potassium sulphate was outperformed potassium chloride in the first and second season the maximum grain yield was 3.31 and 3.65 ton/fed with a load applied to $75 \mathrm{~kg} \mathrm{~K}_{2} \mathrm{O} / \mathrm{fed}$ and with 2 week pattern with potassium sulphate

Maize grain and straw yield increased as increasing of potassium fertilizers this might be due to the $\mathrm{K}$ supply, eases back plant growth and decreases biomass production accordingly, increasing potassium fertilization resulting in an increase in cereal and straw production.

Table 4: Effect of different potassium sources of application on grain yield (ton/fed.) of maize plants grown under fertigation system in both seasons.

\begin{tabular}{|c|c|c|c|c|c|c|c|c|c|}
\hline \multirow{3}{*}{ Fertilizers } & \multirow{3}{*}{$\begin{array}{c}\text { Rates } \\
\text { (Kg/fed) }\end{array}$} & \multicolumn{3}{|c|}{ Pattern } & \multirow[b]{2}{*}{ Mean } & \multicolumn{3}{|c|}{ Pattern } & \multirow[b]{2}{*}{ Mean } \\
\hline & & A week & $\begin{array}{c}\text { Two } \\
\text { weeks }\end{array}$ & Month & & A week & $\begin{array}{c}\text { Two } \\
\text { weeks }\end{array}$ & Month & \\
\hline & & \multicolumn{4}{|c|}{2018} & \multicolumn{4}{|c|}{2019} \\
\hline Control & 0.0 & 2.86 & 2.88 & 2.87 & 2.87 & 3.01 & 3.05 & 3.01 & 3.02 \\
\hline \multirow{3}{*}{$\begin{array}{c}\text { Potassium } \\
\text { sulphate }\end{array}$} & 25 & 2.87 & 3.22 & 3.05 & 3.05 & 3.14 & 3.40 & 3.22 & 3.25 \\
\hline & 50 & 3.05 & 3.29 & 3.17 & 3.17 & 3.26 & 3.47 & 3.34 & 3.36 \\
\hline & 75 & 3.17 & 3.31 & 3.25 & 3.24 & 3.43 & 3.65 & 3.50 & 3.53 \\
\hline \multirow{3}{*}{$\begin{array}{c}\text { Potassium } \\
\text { chloride }\end{array}$} & 25 & 3.24 & 3.07 & 2.97 & 3.09 & 3.07 & 3.17 & 3.10 & 3.11 \\
\hline & 50 & 3.09 & 3.13 & 3.07 & 3.10 & 3.09 & 3.23 & 3.19 & 3.17 \\
\hline & 75 & 3.10 & 3.18 & 3.09 & 3.12 & 3.14 & 3.26 & 3.20 & 3.20 \\
\hline \multicolumn{2}{|c|}{ Mean } & 3.05 & 3.15 & 3.07 & 3.09 & 3.16 & 3.32 & 3.22 & 3.23 \\
\hline \multirow{3}{*}{ LSD $_{0.05}$} & & Sources & \multicolumn{2}{|c|}{0.12} & & \multicolumn{4}{|c|}{0.14} \\
\hline & & Rates & \multirow{2}{*}{\multicolumn{2}{|c|}{$\begin{array}{c}0.11 \\
0.06\end{array}$}} & & \multicolumn{4}{|c|}{0.12} \\
\hline & & Pattern & & & & & & & \\
\hline
\end{tabular}

These concurring interpretations emphasized the importance of potassium because of its involvement in numerous physiological processes, the impact of potassium on water relations, photosynthesis, assimilation transport, and enzymatic initiation that have direct consequences on crop efficiency (Davis 2019). 


\subsection{Straw yield (ton/fed)}

Data on maize levels affected by potassium sulphate and potassium chloride are given in Table (5). There were continuous increases in growth characteristics, (plant height, grain yield, and straw yield) as the fertilizer rate increased from 25,50 , or $75 \mathrm{~kg} \mathrm{~K}_{2} \mathrm{O} / \mathrm{fed}$.

Table (5) showed that the increase in straw yield potassium sulphate treatments more noteworthy than with potassium chloride during in both seasons, respectively. The maximum straw yield was 6.02 and $6.35 \mathrm{ton} / \mathrm{fed}$ with a load applied to $75 \mathrm{~kg}_{\text {of }} \mathrm{K}_{2} \mathrm{O} / \mathrm{fed}$ and a fourteen days pattern with potassium sulphate. This is concurring with (Muhammad et al., 2011).

Table 5: Effect of different potassium sources of application on straw yield (ton/fed) of maize plants grown under fertigation system in both seasons.

\begin{tabular}{|c|c|c|c|c|c|c|c|c|c|}
\hline \multirow{3}{*}{ Fertilizers } & \multirow{3}{*}{$\begin{array}{c}\text { Rates } \\
\text { (Kg/fed) }\end{array}$} & \multicolumn{3}{|c|}{ Pattern } & \multirow[b]{2}{*}{ Mean } & \multicolumn{3}{|c|}{ Pattern } & \multirow[b]{2}{*}{ Mean } \\
\hline & & A week & $\begin{array}{c}\text { Two } \\
\text { weeks }\end{array}$ & Month & & A week & $\begin{array}{c}\text { Two } \\
\text { weeks }\end{array}$ & Month & \\
\hline & & \multicolumn{4}{|c|}{2018} & \multicolumn{4}{|c|}{2019} \\
\hline Control & 0.0 & 4.97 & 5.17 & 5.07 & 5.07 & 5.25 & 5.27 & 5.24 & 5.25 \\
\hline Potassium & 25 & 5.21 & 5.51 & 5.25 & 5.32 & 5.28 & 5.82 & 5.54 & 5.55 \\
\hline \multirow[t]{2}{*}{ sulphate } & 50 & 5.29 & 5.65 & 5.33 & 5.42 & 5.50 & 5.96 & 5.62 & 5.69 \\
\hline & 75 & 5.32 & 6.02 & 5.77 & 5.70 & 5.62 & 6.35 & 6.09 & 6.02 \\
\hline \multirow{3}{*}{$\begin{array}{l}\text { Potassium } \\
\text { chloride }\end{array}$} & 25 & 4.99 & 5.38 & 5.08 & 5.15 & 5.27 & 5.71 & 5.30 & 5.43 \\
\hline & 50 & 5.14 & 5.59 & 5.25 & 5.33 & 5.35 & 5.83 & 5.47 & 5.55 \\
\hline & 75 & 5.17 & 5.64 & 5.28 & 5.36 & 5.39 & 5.87 & 5.50 & 5.59 \\
\hline Mean & & 5.16 & 5.57 & 5.29 & 5.34 & 5.38 & 5.83 & 5.54 & 5.58 \\
\hline \multirow{3}{*}{ LSD $_{0.05}$} & & Sources & \multicolumn{2}{|c|}{0.69} & & \multicolumn{4}{|c|}{0.84} \\
\hline & & Rates & \multirow{2}{*}{\multicolumn{2}{|c|}{$\begin{array}{c}0.13 \\
0.16\end{array}$}} & & \multicolumn{4}{|c|}{0.16} \\
\hline & & Pattern & & & & & & & \\
\hline
\end{tabular}

\subsection{Potassium (\%)}

Table (6) showed that all treatments adopted with potassium sulphate and potassium chloride showed significant statistical effects on the percentage of potassium in maize grains during both seasons. Potassium sulphate significantly exceeded potassium chloride in $\mathrm{K}$ concentration in both seasons.

The greatest potassium rate was 1.97 and $2.06 \%$ with application to $75 \mathrm{~kg}$ of $\mathrm{K}_{2} \mathrm{O} / \mathrm{kg} / \mathrm{fed}$ and fourteen days pattern with potassium sulphate. The noticed rate increment of potassium in grains is expected to be a rate increment of potassium application. It could be explained with increasing nutrient availability is as indicated by (Oosterhuis et al., 2014). Additionally, Pettigrew (2008) referenced that potassium is associated with the enactment of in excess of 60 enzymes, vital for fundamental plant processes, for example, energy use, starch synthesis, nitrogen digestion and respiration.

Table 6: Effect of different potassium sources of application on potassium (\%) in grains of maize plants grown under fertigation system in the both seasons.

\begin{tabular}{|c|c|c|c|c|c|c|c|c|c|}
\hline \multirow{3}{*}{ Fertilizers } & \multirow{3}{*}{$\begin{array}{c}\text { Rates } \\
\text { (Kg/fed) }\end{array}$} & \multicolumn{3}{|c|}{ Pattern } & \multirow[b]{2}{*}{ Mean } & \multicolumn{3}{|c|}{ Pattern } & \multirow[b]{2}{*}{ Mean } \\
\hline & & A week & $\begin{array}{c}\text { Two } \\
\text { weeks }\end{array}$ & Month & & A week & $\begin{array}{c}\text { Two } \\
\text { weeks }\end{array}$ & Month & \\
\hline & & \multicolumn{4}{|c|}{2018} & \multicolumn{4}{|c|}{2019} \\
\hline Control & 0.0 & 1.71 & 1.76 & 1.74 & 1.74 & 1.78 & 1.89 & 1.82 & 1.83 \\
\hline \multirow{3}{*}{$\begin{array}{c}\text { Potassium } \\
\text { sulphate }\end{array}$} & 25 & 1.82 & 1.95 & 1.89 & 1.89 & 1.91 & 2.04 & 1.99 & 1.98 \\
\hline & 50 & 1.90 & 1.96 & 1.92 & 1.93 & 1.98 & 2.05 & 2.01 & 2.01 \\
\hline & 75 & 1.92 & 1.97 & 1.94 & 1.94 & 2.02 & 2.06 & 2.03 & 2.04 \\
\hline \multirow{3}{*}{$\begin{array}{c}\text { Potassium } \\
\text { chloride }\end{array}$} & 25 & 1.8 & 1.93 & 1.87 & 1.87 & 1.86 & 2.00 & 1.94 & 1.93 \\
\hline & 50 & 1.88 & 1.94 & 1.90 & 1.91 & 1.94 & 2.01 & 1.96 & 1.97 \\
\hline & 75 & 1.90 & 1.95 & 1.91 & 1.92 & 1.97 & 2.02 & 1.98 & 1.99 \\
\hline \multicolumn{2}{|c|}{ Mean } & 1.85 & 1.92 & 1.88 & 1.88 & 1.92 & 2.01 & 1.96 & 1.96 \\
\hline \multirow{3}{*}{ LSD $_{0.05}$} & & Sources & & 0.02 & & \multicolumn{4}{|c|}{0.03} \\
\hline & & Rates & & 0.07 & & \multicolumn{4}{|c|}{0.06} \\
\hline & & Pattern & & 0.05 & & \multicolumn{4}{|c|}{0.04} \\
\hline
\end{tabular}




\subsection{Total carbohydrates $(\%)$}

Table (7), which plainly shows that all potassium sulfate and potassium chloride treatments altogether expanded the total carbohydrate amount of the maize grains contrasted with the control over the two seasons.

The maximum increase in total carbohydrates in both seasons was recorded by potassium sulphate compared to potassium chloride in the first and second seasons, respectively. On other hand the maximum height of the plants was 74.65 and $76.24 \%$ with application to $75 \mathrm{~kg}$ of $\mathrm{K}_{2} \mathrm{O} /$ fed and a 2 pattern with potassium sulphate. Data likewise uncovered that potassium sulfate outperformed potassium chloride in such manner with a critical contrast in the two seasons. This outcome is as per Amanullah, et al., (2016).

Table 7: Effect of different potassium sources on total carbohydrates (\%) in maize gains plants grown under fertigation system.

\begin{tabular}{|c|c|c|c|c|c|c|c|c|c|}
\hline \multirow{3}{*}{ Fertilizers } & \multirow{3}{*}{$\begin{array}{c}\text { Rates } \\
\text { (Kg/fed) }\end{array}$} & \multicolumn{3}{|c|}{ Pattern } & \multirow[b]{2}{*}{ Mean } & \multicolumn{3}{|c|}{ Pattern } & \multirow[b]{2}{*}{ Mean } \\
\hline & & A week & $\begin{array}{c}\text { Two } \\
\text { weeks }\end{array}$ & Month & & A week & $\begin{array}{c}\text { Two } \\
\text { weeks }\end{array}$ & Month & \\
\hline & & \multicolumn{4}{|c|}{2018} & \multicolumn{4}{|c|}{2019} \\
\hline Control & 0.0 & 65.79 & 66.67 & 66.00 & 66.15 & 68.29 & 69.66 & 68.65 & 68.87 \\
\hline \multirow{3}{*}{$\begin{array}{l}\text { Potassium } \\
\text { sulphate }\end{array}$} & 25 & 66.67 & 71.56 & 69.67 & 69.30 & 71.16 & 73.3 & 71.39 & 71.95 \\
\hline & 50 & 68.00 & 72.43 & 71.00 & 70.48 & 71.38 & 74.42 & 72.53 & 72.78 \\
\hline & 75 & 70.47 & 74.65 & 71.60 & 72.24 & 72.49 & 76.24 & 72.73 & 73.82 \\
\hline \multirow{3}{*}{$\begin{array}{l}\text { Potassium } \\
\text { chloride }\end{array}$} & 25 & 65.69 & 70.56 & 67.01 & 67.75 & 68.89 & 72.06 & 69.14 & 70.03 \\
\hline & 50 & 68.67 & 71.65 & 70.67 & 70.33 & 70.13 & 73.18 & 72.17 & 71.83 \\
\hline & 75 & 69.67 & 73.43 & 71.00 & 71.37 & 71.15 & 74.99 & 72.51 & 72.88 \\
\hline Mean & & 67.85 & 71.56 & 69.56 & 69.66 & 70.50 & 73.41 & 71.30 & 71.74 \\
\hline \multirow{3}{*}{ LSD $_{0.05}$} & & Sources & \multicolumn{2}{|c|}{1.35} & & \multicolumn{4}{|c|}{0.57} \\
\hline & & Rates & \multicolumn{2}{|c|}{1.06} & & \multicolumn{4}{|c|}{0.90} \\
\hline & & Pattern & \multicolumn{2}{|c|}{0.90} & & \multicolumn{4}{|c|}{0.94} \\
\hline
\end{tabular}

\subsection{Oil (\%)}

Table (8) shows that potassium manures essentially expanded the oil rate in maize grains over the two seasons. Furthermore, the outcomes demonstrated that maize grains treated with potassium sulfate altogether surpassed the level of potassium chloride oil in the two seasons.

The maximum percentage of oil in the grains was 5.67 and $6.22 \%$ with application at $75 \mathrm{~kg}$ $\mathrm{K}_{2} \mathrm{O} /$ fed and two pattern with potassium sulphate, where sulphur ( $\mathrm{S}$ ) is plays role assumes part in structural constituent of some amino acids such as cysteine.

Similar investigations were also obtained by Hussain et al., (2013). In this concern, Tränkner et al., 2018 found that potassium fertilizers increased oil content of corn grains.

Table 8: Effect of different potassium sources of application on oil (\%) in grains of maize plants grown under fertigation system in both seasons.

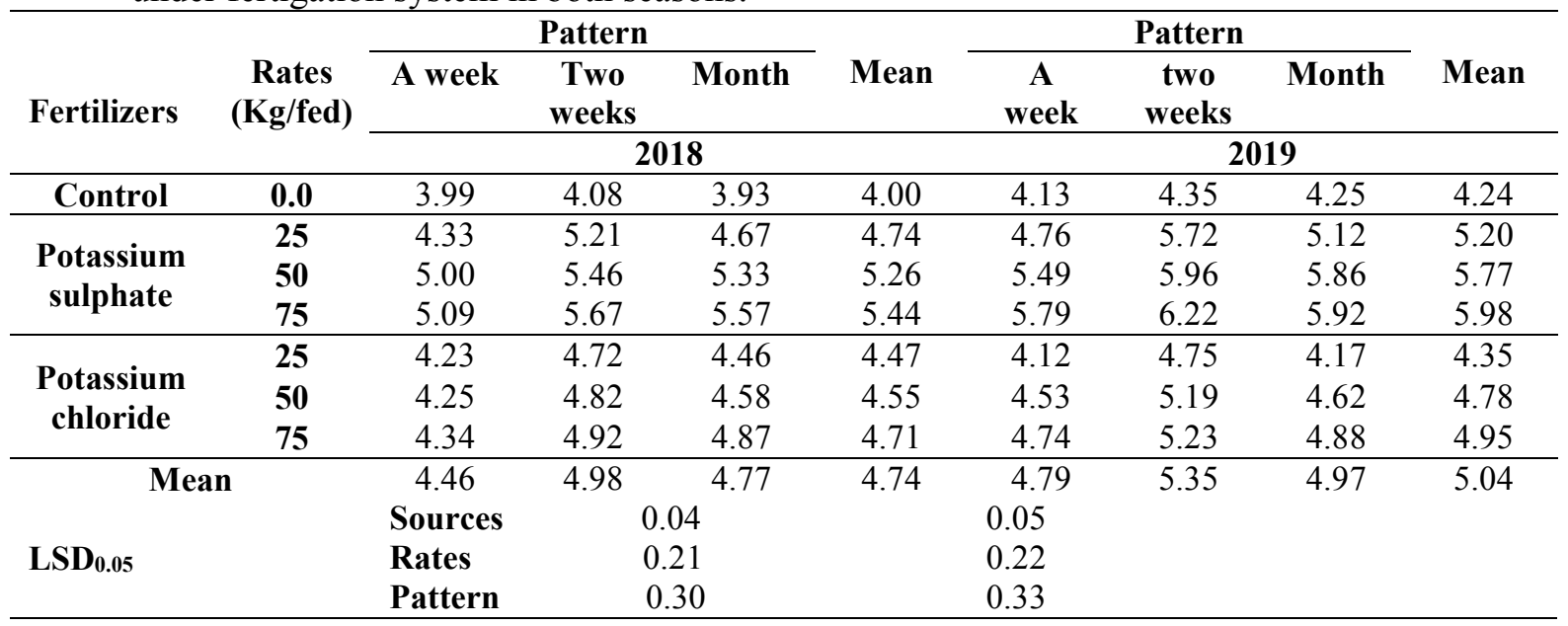




\subsection{Economic feasibility}

The data in Table 9 shows the cost-effectiveness calculations for the utilization of potassium sulphate and potassium chloride fertilizers in this study. The cost of inputs, outputs and net income of the treatments tested are presented in the table for maize cultivation.

The current data concluded that, under the same conditions of this study, the use of potassium sulfate fertilizer at the pace of $75 \mathrm{~kg} /$ took care of to the maize plant was more viable than the utilization of potassium chloride at similar dosages, where this treatment not just expanded the yield productivity for the maize plant, yet additionally expanded their retention of K. Additionally, the obtained data contributes essentially to delivering the most noteworthy overall gain 28545 L.E of potassium sulfate. The results obviously demonstrate that applying potassium to maize cultivation is more valuable under fertigation. This shows that the use of potassium fertilizer is more valuable to acquire the best return of corn during the two study seasons.

The economic feasibility calculated from the input/output ratio showed a higher yield ratio of potassium sulphate fertilizer than potassium chloride fertilizer. It could be concluded that applying $\mathrm{K}$ fertilizer doses by fertigation is more beneficial to accomplish maximum yield, better net yield and higher net yield for maize producers rather than insisting as opposed to demanding soil application.

Table 9: Economic feasibility of potassium fertilizers sources on yield of maize plant grown on a sandy soil under fertigation system (Average of two years).

\begin{tabular}{lccccccc}
\hline Fertilizers types & $\begin{array}{c}\text { Amount } \\
\text { of } \\
\text { Fertilizers }\end{array}$ & $\begin{array}{c}\text { Price } \\
\text { (L.E.) }\end{array}$ & $\begin{array}{c}\text { Grain } \\
\text { yield } \\
\text { (ton/fed) }\end{array}$ & $\begin{array}{c}\text { Price } \\
\text { (L.E.) }\end{array}$ & $\begin{array}{c}\text { Straw } \\
\text { yield } \\
\text { (ton/fed) }\end{array}$ & $\begin{array}{c}\text { Price } \\
\text { (L.E.) }\end{array}$ & $\begin{array}{c}\text { Total } \\
\text { yield } \\
\text { income }\end{array}$ \\
\hline Control & 0.0 & 0.0 & 2.95 & 23600 & 5.16 & 2580 & 26180 \\
Potassium sulfate & 75 & 600 & 3.22 & 25760 & 5.57 & 2785 & 28545 \\
Potassium chloride & 75 & 525 & 3.05 & 24400 & 5.36 & 2680 & 27080 \\
\hline $\begin{array}{l}\text { Grain yield of maize }=\text { 8000 L.E/ton } \\
\text { Potassium Sulphate }=\text { 8000 L.E/ton }\end{array}$ & & & & \multicolumn{2}{c}{ Straw yield of maize $=500$ L.E/ton } \\
\end{tabular}

\section{Discussion}

The potassium sources affect the growth of the maize with an increased level of potassium. Along these lines, the addition of potassium fertilizers increased the growth and yield of maize plants. It very well might be because of the increasing of photosynthesis by the utilization of potassium (Davis 2019).

As well the sulfate bunch $\left(\mathrm{SO}_{4}\right)$ assumes a significant part in the arrangement of certain proteins which eventually positively affects plant growth and also sulfur (S) is a significant structural constituent of some amino acids like cysteine. Comparative examinations were likewise gotten by Hussain et al., (2013).

The current study revealed that potassium sulphate and potassium chloride added to maize plant, there was a significant increase in $\mathrm{K} \%$, carbohydrates, and oil of grains. Likewise, grains and straw yield increased significantly from the adding of $75 \mathrm{~kg} \mathrm{~K}_{2} \mathrm{O} / \mathrm{fed}$. of potassium sulphate fertilizer with 2 week pattern under fertigation in sandy soil. These outcomes follow those acquired from Muhammad et al., (2011).

On other hands, potassium sulphate effect for exceeded potassium chloride in both seasons. This might be because of that, potassium chloride leaches down the profile during irrigation. The higher growth of potassium-treated plant compared to control could be due to the porosity of potassium, which allowed more water to be held in the soil. Another hypothesis is that extra supplements, particularly phosphorus, could be accessible to potassium-treated plants because of the debris content of roast, regardless of continuous flushing.

\section{Conclusion}

The study indicated that the response of corn to potassium sulphate and potassium chloride addition at a rate of $75 \mathrm{~kg} / \mathrm{fed}$ was better than the other rates by addition, plant height, grain yield, straw yields, $\mathrm{K} \%$, carbohydrate $\%$, and oil \% improved by adding of potassium fertilizer. At last, it showed that the results of application $\mathrm{K}$ improve growth, increased yield, and yield components of corn crops under fertigation. 
It could be concluded that, the application of $\mathrm{K}$ at $75 \mathrm{~kg}$ of potassium sulphate with a 2 -week pattern improved corn growth traits, increased yield and quality as well increased fertigated producer income in sandy soil where, sulphate fertilizer, K-source is a cheaper and rich source of potassium.

\section{Acknowledgements}

The authors are grateful to the director of a private farm in Wadi El-Natroun, El-Behaira governorate, Egypt, for providing all the facilities necessary to carry out the research.

\section{References}

A.O.C.S. 2019. Official methods of the Association of Official Analysis Chemists $21^{\text {th }}$ Edition.Association of Official analytical Chemists, Arlington, Virginia, U.S.A. https://law.resource.org/pub/us/cfr/ibr/002/aoac.methods.1.1990.pdf

Amanullah, I.I., and H. Zeeshan, 2016. Potassium management for improving growth and grain yield of maize (Zea mays L.) under moisture stress condition. Sci. Rep., 6, 34627.

Doi: $10.1038 /$ srep34627

Bao, S. 2000. Agrochemical analysis of soil. Beijing: Agricultural Publish House of China.

Barker, A.V., J. David and D.J. Pilbeam, 2015. Handbook of plant nutrition. Second Edition. CRC Press. https://doi.org/10.1201/b18458

Cottenie, A., M. Verloo, L. Kiekens, G. Velghe, and R. Camerlynck, 1982.Chemical analysis of plant and soil. In: Laboratory of Analytical and Agro Chemistry State Univ. Ghent, Belguim, Article No. 42: 80-284. https://www.scirp.org

Carter, M.R. and E.G. Gregorich, 2008. Soil sampling and methods of analysis, second edition, Canadian Society of Soil Science by Taylor \& Francis Group, LLC. $\mathrm{http}: / / \mathrm{www} \cdot$ taylorandfrancis.com.

Davis, R., 2019. Potassium fertilization effects on yield for wheat, soybean, and corn grown in coastal plain soils. (Master's thesis). https://scholarcommons.sc.edu/etd/5473

Dubois, M., K.A. Gilles, J.K. Hamition, and P.A. Rebers, 1956. Colorimetric method for determination of sugars and related substances. Anal. Chem., 28:350-356. https://doi.org/10.1021/ac60111a017

Hussain, Z., R.A. Khattak, M. Irshad, and A.E. Eneji, 2013. Ameliorative effect of potassium sulphate on the growth and chemical composition of wheat (Triticum aestivum L.) in salt effected soils. J. Soil Sci. Plant Nutr., 13(2):401-415. https://scielo.conicyt.cl/pdf/jsspn/v13n2/aop3213.pdf

Karam, F., R. Massaad, S. Skaf, J. Breidy, and Y. Rouphael, 2011. Potato response to potassium application rates and timing under semi-arid conditions.Adv. Hortic. Sci., 265-268. Doi:10.13128/ahs-12761

Khan, M.Z., M.E. Akhtar, M. Mahmood-ul-Hassan, M.M. Mahmood, and M.N. Safdar, 2012. Potato tuber yield and quality as affected by rates and sources of potassium fertilizer. J. Plant Nutr., 35:664-677. Doi:10.1080/01904167.2012.653072

Kumar, D. and N.A. Jhariya, 2013. Nutritional, Medicinal and Economical Importance of Corn: A Mini Review. Res. J. of Pharmaceutical Sci., 2:7-8. www.isca.in/IJPS/Archive/v2/i7/2.ISCA-RJPcS2013-029.pdf

Muhammad, T., S. Ahmad, N. Muhammad, A. Ishaq, and A. Muhammad, 2011.Effect of potassium rates and sources on the growth.Sarhad J. Agric., 27(3):415-422. https://www.aup.edu.pk/sj_pdf/effect\%20of\%20potacium\%20rates.PDF

Mulyati, B.A.B. and R.S. Tejowulan, 2021. Improving Maize (Zea mays L.) growth and yield by the application of inorganic and organic fertilizers plus. Earth and Environ. Sci., 712. doi:10.1088/1755-1315/712/1/012027

Nelson, D.W. and L. Sommers, 1982.Total carbon, organic carbon, and organic matter 1.Methods of soil analysis.Part 2.Chemical and microbiological properties, (methods of soilan 2), 539-579. https://doi.org/10.2134/agronmonogr9.2.2ed.c29

Oosterhuis, D.M., D.A. Loka, E.M. Kawakami, and W.T. Pettigrew, 2014.The physiology of potassium in crop production. Adv. Agron., 126:203-233. Doi:10.1016/B978-0-12-800132-5.00003-1 
Pettigrew, W.T., 2008. Potassium influences on yield and quality production for maize, wheat, soybean and cotton. Physiol. Plant, 133:670-681.Doi: 10.1111/j.1399-3054.2008.01073.x

Snedecor, G.W. and W.G. Cochran, 1990. Statistical Methods, the Iowa State Univ. $8^{\text {th }}$ Ed. Iowa State. Univ., Press, Ames Iowa, U.S.A. https://doi.org/10.3102/10769986019003304

Tränkner, M., E. Tavakol, and B. Jákli, 2018. Functioning of potassium and magnesium in photosynthesis, photosynthate translocation and photoprotection. Physiol. Plant, 163:414-431. https://doi.org/10.1111/ppl.12747. 